\title{
Effect of palmitic acid and linoleic acid on expression of ICAM-1 and VCAM-1 in human bone marrow endothelial cells (HBMECs)
}

Nima Sanadgol', Ali Mostafaie², Kamran Mansouri², Gholamreza Bahrami²

1Department of Biology, College of Science, Zabol University, Iran

${ }^{2}$ Medical Biology Research Center, Kermanshah University of Medical Sciences,

Kermanshah, Iran

Submitted: 30 January 2011

Accepted: 9 September 2011

Arch Med Sci 2012; 8, 2: 192-198

DOI: $10.5114 /$ aoms.2012.28544

Copyright @ Termedia \& Banach

\section{Abstract}

Introduction: The amount and type of fatty acids (FAs) in the diet influence the risk of atherosclerosis. Palmitic acid and linoleic acid exist at high levels in Iranian edible oils. In this study, we investigated the effect of palmitic acid and linoleic acid on expression of soluble and cell-associated forms of intercellular adhesion molecule-1 (ICAM-1) and vascular cell adhesion molecule-1 (VCAM-1) in human bone marrow endothelial cells (HBMECs).

Material and methods: The endothelial cells were induced with bacterial lipopolysaccharide (LPS) or tumor necrosis factor $\alpha$ (TNF- $\alpha$ ), and thereafter incubated with palmitic or linoleic acid. The level of soluble and cell-associated VCAM-1 and ICAM-1 were analyzed using ELISA and western blot.

Results: Our findings indicated that palmitic acid up-regulates the expression of ICAM- 1 and VCAM-1 in HBMECs when these cells are induced with TNF- $\alpha$ or LPS. In addition, the results suggest that linoleic acid could sustain up-regulated ICAM-1 and VCAM-1 in activated endothelial cells.

Conclusions: Chronic activation of endothelial cells in the presence of palmitic and linoleic may account for pathogenesis of cardiovascular events. These findings provide further support for the detrimental effects of these fatty acids, especially palmitic acid, in promotion and induction of cardiovascular diseases which are prevalent in the Iranian population.

Key words: human bone marrow endothelial cells, intercellular adhesion molecule-1, fatty acid, vascular cell adhesion molecule-1.

\section{Introduction}

Research conducted by the Iranian Nutrition Institute (INI) showed that roughly $21 \%$ of the population's food intake results from the consumption of edible oils. If the intake of other fats contained in other food products are taken into account, this percentage would exceed $30 \%$, the maximum recommended amount of consumption. Iran will experience a significant increase in both per capita and total consumption of edible oils and feed meals over the next 10 years [1]. Palmitic acid (C16:0) and linoleic acid $(\mathrm{C} 18: 2 \mathrm{n} 6)$ are the most common saturated and polyunsaturated fatty acids consumed in the Iranian population, respectively [2]. The amount and type of fatty acids in the diet influence the risk of inflammatory disease and atherosclerosis [3, 4]. Fats rich in long-chain saturated fatty acids (SFA)

\author{
Correspondening author: \\ Ali Mostafaie PhD \\ Medical Biology \\ Research Center \\ P.O. Box: 6714869914 \\ Sorkheh Lizheh \\ Kermanshah, Iran \\ Phone: 98-831-4279923 \\ Fax: 98-831-4276471 \\ E-mail: \\ amostafaie@kums.ac.ir, \\ amostafaie@mbrc.ac.ir
}


such as butter have been shown to exacerbate postprandial lipemic responses [5]. Current dietary recommendations for reducing cardiovascular disease (CVD) risk emphasize reducing the intake of SFA (mainly palmitic acid) by increasing dietary monounsaturated fatty acids (MUFA) $[6,7]$. On the other hand, the findings regarding the detrimental effect of linoleic acid, n-6 polyunsaturated fatty acids (PUFA) abundant in many vegetable oils, on cardiovascular disease are controversial [8-12].

Atherosclerosis is thought to be initiated at critical sites of the arterial vasculature by a process of leukocyte adhesion to the vessel wall, sustained by the occurrence of active functional changes on the endothelial surface [13]. Normally, vascular endothelial cells have low adhesiveness for leukocytes. However, when stimulated, they express adhesion molecules at their surfaces responsible for firm attachment/activation of leukocytes and initiation of inflammation. The members of the immunoglobulin gene superfamily of adhesion molecules, intercellular adhesion molecule-1 (ICAM-1) and vascular cell adhesion molecule-1 (VCAM-1), are among the most prominent adhesion molecules. These adhesion molecules interact with integrins at cellular surfaces and control the traffic of leukocytes between blood and tissues [14-17]. Human bone marrow endothelial cells (HBMECs), a representative of microvascular endothelial cells, synthesize the adhesion molecules to control the traffic of hematopoietic cells from and to the blood [18-20].

Previously, we reported that elaidic acid sustains ICAM-1 and VCAM-1 up-regulated by tumour necrosis factor $\alpha$ (TNF- $\alpha$ ) or lipopolysaccharide (LPS) [21]. Herein, we have investigated the effect of palmitic acid and linoleic acid, the two most common fatty acids consumed in Iran, on expression of membrane and secreted forms of VCAM-1 and ICAM-1 in HBMECs, in order to determine the probable relationship between immoderate consumption of these FAs and high atherosclerosis prevalence in the Iranian population.

\section{Material and methods}

\section{Chemicals and cells}

Seventy five $\mathrm{cm}^{2}$ culture flasks, culture microplates (NUNC, Roskilde, Denmark), trypsin/ EDTA solution, MCDB131, penicillin, streptomycin, amphotericin B, fetal bovine serum (FBS) (Gibco, New York, USA), free essential fatty acid - bovine serum albumin (FEFA-BSA), palmitic acid (C16), linoleic acid (C18:2n6) and human recombinant TNF- $\alpha$ (T 0157) were purchased from Sigma (St. Louis, MO, USA). LPS (31.6-25 Bacto) was purchased from DIFCO (Kansas, USA). Monoclonal antibodies against VCAM-1 (AHT0603) and ICAM-1 (AHS5444), ELISA-based kits (96 wells) for SICAM-1 (KHS4412/ KHS5411) and
sVCAM-1(KHT0611) were purchased from Biosource (Invitrogen Corp. USA). Rabbit anti-mouse IgG (horseradish peroxidase conjugated) was prepared in our laboratory. The HBMECs were kindly provided by Dr. Manocher Mirshahi (College of Medical Sciences, Tarbiat Modares University, Tehran, Iran).

\section{Endothelial cell culture}

The HBMECs at the 25th passage were cultured in a complete medium containing MCDB131 supplemented with $10 \% \mathrm{FBS}, 100 \mathrm{lu} / \mathrm{ml}$ penicillin, 100 $\mu \mathrm{g} / \mathrm{ml}$ streptomycin in $75 \mathrm{~cm}^{2}$ culture flasks at $37^{\circ} \mathrm{C}$ and $5 \% \mathrm{CO}_{2}$. After reaching confluence, the cells were treated with trypsin-EDTA and plated to yield near-confluent cultures at the end of the experiment. The freshly plated cells were allowed to attach in standard growth medium for at least $48 \mathrm{~h}$. The HBMECs were pretreated with TNF- $\alpha$ or LPS for induction of adhesion molecule expression, and then treated with palmitic or linoleic acid according to the experimental design (see below).

\section{Experimental design}

Cultured HBMECs were incubated with two different concentrations of TNF- $\alpha$ (0.01 and 0.001 $\mu \mathrm{g} / \mathrm{ml})$ and three different concentrations of LPS $(0.1,1$ and $10 \mu \mathrm{g} / \mathrm{ml})$ for $6,12,18$ and $24 \mathrm{~h}$ to find optimal concentrations and incubation times of these stimulants. In separate experiments, the cultured HBMECs were also incubated with three different concentrations $(10,50$ and $100 \mu \mathrm{M})$ of fatty acids (palmitic or linoleic acid) for 24,48 and $72 \mathrm{~h}$ to find optimal concentrations of these fatty acids with minimal toxic effects. Palmitic and linoleic acid were converted to their potassium salts through the saponification method [22], then aliquoted under an $\mathrm{N}_{2}$ stream, and stored at $-80^{\circ} \mathrm{C}$ for no longer than 5 months before use. At the time of the experiments, fatty acids were dissolved in FEFA-BSA at the final desired concentrations. The fatty acid stock solutions were diluted in the medium to reach fatty acid concentrations of $10 \mu \mathrm{M}$ to $100 \mu \mathrm{M}$ with corresponding BSA concentrations of $2 \mu \mathrm{M}$ to $20 \mu \mathrm{M}$ (molar ratio of fatty acid to albumin was $5: 1$ ) [23]. Equivalent amounts of BSA alone were added to control plates. At the end of these periods, the protein pattern (SDS-PAGE) and parameters of cell viability (morphology, number and viability (trypan blue exclusion)) were assessed. The best concentrations with maximum viability and protein expression for each TNF- $\alpha$, LPS and fatty acids were selected. All experiments were performed at least in triplicate.

\section{Fatty acid treatment}

Fatty acid $(1000 \mu \mathrm{M}) / \mathrm{BSA}(200 \mathrm{mM})$ stock solutions were prepared by dissolving FEFA-BSA and 
palmitic or linoleic acid (potassium salts) in normal saline (sodium chloride $0.9 \% \mathrm{w} / \mathrm{v}$ ). The filter-sterilized fatty acids-BSA mixture $(0.5 \mathrm{ml})$ was added to $4.5 \mathrm{ml}$ of fresh MCDB131 medium supplemented with 10\% fetal bovine serum (FBS) (final concentration of fatty acids $100 \mu \mathrm{M})$. The cells incubated in MCDB131 and BSA (20 mM) supplemented with $10 \%$ FCS in absence of fatty acids, TNF- $\alpha$, or LPS were used as negative controls.

\section{Detection of cell adhesion molecules}

Assay of cell adhesion molecules was carried out by both ELISA and western blot analysis.

\section{ELISA}

The HBMECs were cultured in $75 \mathrm{~cm}^{2}$ culture flasks and allowed to reach confluence. After adding the stimulants and fatty acids, soluble (in supernatant) and cell-associated (in cell lysate) forms of ICAM-1 and VCAM-1 were quantified using the ELISA kits, based on a sandwich format. For preparation of cell lysate, the endothelial cells were washed three times with PBS and solubilized in Tris$\mathrm{HCl}$ buffer (20 mM, pH 8.0), containing 1\% NP-40, $1 \%$ CHAPS, $50 \mathrm{mM} \mathrm{NaCl}, 10 \%$ glycerol, $2 \mathrm{mM}$ EDTA and $1 \mathrm{mM}$ PMSF overnight at $4^{\circ} \mathrm{C}$. The cell lysate was centrifuged at $10000 \times \mathrm{g}$ for $10 \mathrm{~min}$ at $4^{\circ} \mathrm{C}$ and the clear supernatant was immediately used for determination of ICAM-1 and VCAM-1. The data presented are means of triplicate determinations.

\section{Western blot analysis}

The HBMECs were grown to confluence in $75 \mathrm{~cm}^{2}$ culture flasks, gently washed twice with icecold Tris- $\mathrm{HCl}$ buffer $(10 \mathrm{mM})$ containing $250 \mathrm{mM}$

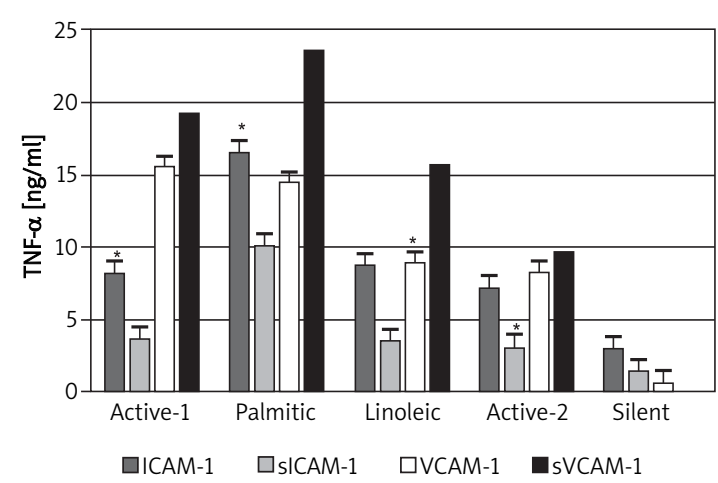

Figure 1. Effect of palmitic and linoleic acid on level of soluble and cell associated ICAM-1 and VCAM-1 in TNF- $\alpha$-stimulated HBMECs. Cells pre-treated with TNF- $\alpha$, thereafter with palmitic and linoleic acid $(100 \mu \mathrm{M}$ for $24 \mathrm{~h})$. Active- 1 is HBMECs treated with TNF- $\alpha$ ( $1 \mathrm{ng} / \mathrm{ml}$ for $12 \mathrm{~h}$ ). Active- 2 is active- 1 cells in culture medium without TNF- $\alpha$ for additional $24 \mathrm{~h}$. Silent is HBMECs in culture medium without TNF- $\alpha$ and fatty acid. Each column shows the mean \pm SD of triplicate determinations ${ }^{*} p<0.05$ sucrose and then lysed in $0.5 \mathrm{ml}$ of lysis buffer (20 mM Tris- $\mathrm{HCl} \mathrm{pH} 7.4$ containing $50 \mathrm{mM} \mathrm{NaCl}, 1 \%$ NP-40, 10\% glycerol, 1 mM PMSF, 2 mM EDTA and $10 \mu \mathrm{g} / \mathrm{ml}$ aprotinin). After $10 \mathrm{~min}$ on ice, cell lysates were collected by centrifugation $(14000 \times \mathrm{g}$ for $15 \mathrm{~min}$ at $\left.4^{\circ} \mathrm{C}\right)$. The supernatant was boiled in SDSPAGE sample buffer containing 10\% SDS for $10 \mathrm{~min}$ and resolved in $12.5 \%$ polyacrylamide separating gels at $150 \mathrm{~V}$. The resolved proteins were transferred to polyvinylidene difluoride (PVDF) membrane using tank blotting [24]. The membranes were rinsed 3 times in phosphate buffered saline (PBS) containing $0.05 \%(\mathrm{v} / \mathrm{v})$ Tween 20 , and then blocked in PBS-BSA $2 \%(\mathrm{w} / \mathrm{v})$ for $2 \mathrm{~h}$. The membranes were incubated overnight (12 h) in primary (mouse antihuman VCAM-1 and ICAM-1 monoclonal antibodies) and for $2 \mathrm{~h}$ in secondary (rabbit anti-mouse lgG, HRP conjugated) antibodies after washing 5 times in each step. Finally, the blots were exposed to HRP substrate solution (TMB and $\mathrm{H}_{2} \mathrm{O}_{2}$ ) for detection of target protein bands. The densities of ICAM- 1 and VCAM-1 bands were determined by Lab works version 4.0 software (UVP, Upland, USA), and the ratios of FAs/control multiplied by 100 and defined as relative expression of ICAM-1 and VCAM-1.

\section{Statistical analysis}

All tests were performed at least three times. Findings of ELISA considered when variations in intra- and inter-assays were less than $5 \%$ and $15 \%$, respectively. The results are expressed as mean \pm SD and were analyzed using either Student's $t$ test for comparison between two groups or ANOVA (analysis of variance) for multiple comparisons. Results were considered significant when $p<0.05$.

\section{Results}

Cultured HBMECs in the absence of stimulants (LPS or TNF- $\alpha$ ) or FAs (palmitic or linoleic acid) expressed very low levels of ICAM-1 or VCAM-1. The results indicated that TNF- $\alpha$ at $1 \mathrm{ng} / \mathrm{ml}$ for $12 \mathrm{~h}$ and LPS at $10 \mu \mathrm{g} / \mathrm{ml}$ for $12 \mathrm{~h}$ induced optimal expression of the adhesion molecules on HBMECs with minimal toxic effects as compared to the control wells. Furthermore, palmitic and linoleic acid up to $100 \mu \mathrm{M}$ for $24 \mathrm{~h}$ or $48 \mathrm{~h}$ did not have a considerable adverse effect on cell count and morphology, and protein pattern as assessed by SDSPAGE (data not shown).

The results of ELISA for assay of cell-associated ICAM-1 showed that TNF- $\alpha$ is a stronger stimulant than LPS for expression of this adhesion molecule. Conversely, LPS could induce sICAM-1 relatively better than TNF- $\alpha$. Furthermore, LPS could stimulate cell associated and SVCAM-1 very strongly (Figures 1, 2). Therefore, depending on the type of inducer (LPS or TNF- $\alpha$ ), one form of the adhesion molecule (soluble 


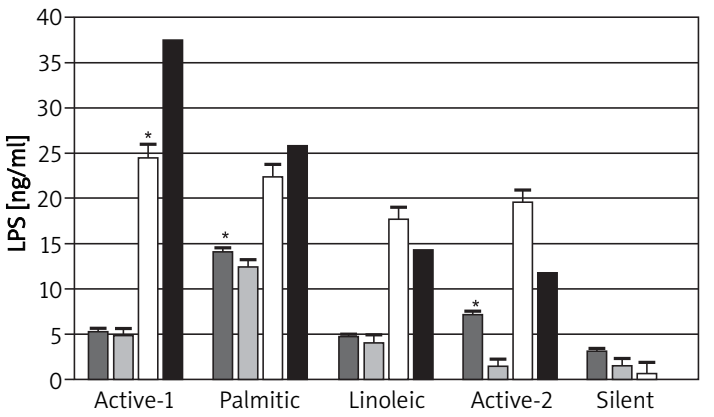

$\square$ ICAM-1 $\square$ sICAM-1 $\square$ VCAM-1 घ sVCAM-1

Figure 2. Effect of palmitic and linoleic acid on level of soluble and cell associated ICAM-1 and VCAM-1 in LPS-stimulated HBMECs. Cells pre-treated with LPS, thereafter with palmitic and linoleic acid (100 $\mu \mathrm{M}$ for $24 \mathrm{~h})$. Active-1 is HBMECs treated with LPS $(10 \mu \mathrm{g} / \mathrm{ml}$ for $12 \mathrm{~h})$. Active- 2 is active-1 cells in culture medium without LPS for additional $24 \mathrm{~h}$. Silent is HBMECs in culture medium without LPS and fatty acid. Each column shows the mean \pm SD of triplicate determinations

${ }^{*} p<0.05$

or cell-associated) was up-regulated more than the other form. The results also indicated that these inducers up-regulate VCAM-1 better than ICAM-1, in whole.

When HBMECs induced by LPS $(10 \mu \mathrm{g} / \mathrm{ml}$ for $12 \mathrm{~h})$ or TNF- $\alpha$ ( $1 \mathrm{ng} / \mathrm{ml}$ for $12 \mathrm{~h})$ were treated with palmitic or linoleic acid (100 $\mu \mathrm{M}$ for $24 \mathrm{~h})$, the level of the adhesion molecules changed remarkably. Palmitic acid significantly enhanced the level of soluble and cell-associated ICAM-1 (ICAM-1 and sICAM-1) and sustained the level of VCAM-1 and sVCAM-1 in HBMECs when these cells induced with LPS or TNF- $\alpha$. In contrast, linoleic acid did not significantly affect the level of soluble or cell associated forms of ICAM- 1 in HBMECs pre-treated with TNF- $\alpha$ or LPS, but to a small extent enhanced the expression of VCAM-1, especially SVCAM-1, when the cells were activated with TNF- $\alpha$ (Figures 1, 2).

Western blot analysis of total cell-associated VCAM-1 and ICAM-1 following treatment of activated HBMECs with palmitic and linoleic acid is demonstrated in Figures 3 and 4, respectively. These results also indicated that palmitic acid significantly induces the expression of ICAM-1 on HBMECs when these cells are primed with TNF- $\alpha$ or LPS, and sustains up-regulated VCAM-1 at an activated level. In contrast, linoleic acid did not affect the level of ICAM-1 when HBMECs were pre-treated with TNF- $\alpha$ or LPS and VCAM-1 when these cells were pre-treated with TNF- $\alpha$. However, linoleic acid decreased the level of VCAM-1 when HBMECs were pre-treated with LPS.

\section{Discussion}

A number of risk factors for CVD have been identified from epidemiological studies. These include positive family history of CVD, cigarette smoking,
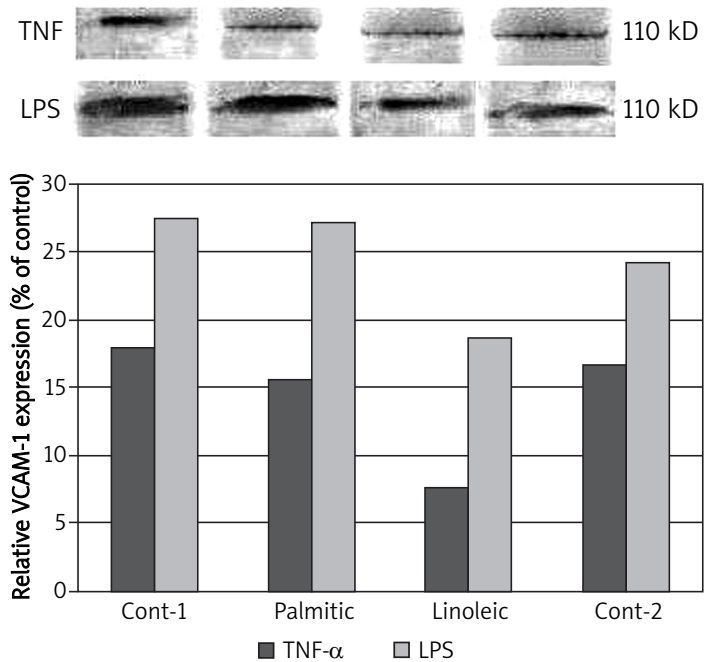

Figure 3. Western blot analysis of VCAM-1 after treatment of HBMECs with palmitic and linoleic acid. Cells stimulated with TNF- $\alpha$ and LPS, and then with palmitic and linoleic acid. Cont-1 is HBMECs grown in medium containing TNF- $\alpha$ or LPS. Cont- 2 is cont1 cells in culture medium without TNF- $\alpha$ or LPS for additional $24 \mathrm{~h}$. Data are representative of three independent experiments
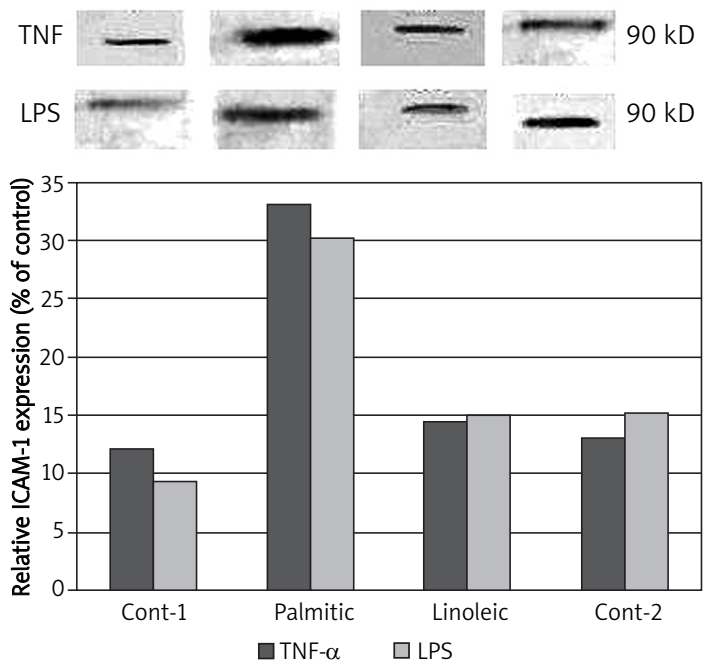

Figure 4. Western blot analysis of ICAM-1 after treatment of HBMECs with palmitic and linoleic acid. Cells stimulated with TNF- $\alpha$ and LPS, and then with palmitic and linoleic acid. Cont-1 is HBMECs grown in medium containing TNF- $\alpha$ or LPS. Cont- 2 is cont1 cells in culture medium without TNF- $\alpha$ or LPS for additional $24 \mathrm{~h}$. Data are representative of three independent experiments

hypertension, elevated serum cholesterol, obesity, diabetes, physical inactivity, sex, age and excessive stress [25]. During the 1950s, considerable interest began to develop concerning a possible relationship between dietary fat and the incidence of coronary heart disease (CHD) [26]. The relationship 
between saturated fat intake and low density lipoprotein (LDL) is direct and progressive, increasing the risk of CVD [27]. According to the results reported by Bahrami et al. [2], edible oil products manufactured in Iran contain remarkably high levels of trans and saturated fatty acids. In addition, the main unsaturated fatty acid in many edible oils consumed in Iran is linoleic acid.

Saturated fatty acids (SFAs) are believed to contribute to induction of CHD [28]. This understanding is based on the evidence that accumulation of SFA in vascular cells leads to lipid-mediated vascular cell dysfunction $[29,30]$. Vascular endothelium, as it is continuously exposed to free fatty acids, plays a critical role in the development of vascularrelated diseases, including atherosclerosis, $C A D$, and diabetes [31, 32]. The HBMECs express the cellular adhesion molecules ICAM-1 and PECAM and also VCAM-1 and ELAM-1 upon activation by stimulatory cytokines such as TNF- $\alpha$ [33]. Our results indicated that LPS, in comparison to TNF- $\alpha$, is a more potent inducer for the soluble form of ICAM-1 (sICAM-1) as well as soluble and cell associated forms of VCAM-1.

Epidemiological studies have shown that soluble ICAM-1 (SICAM-1) is a predictor of CVD among healthy individuals [34-36]. In contrast, levels of soluble VCAM (sVCAM) do not predict primary onset of CVD [36-38] but are markedly elevated in acute coronary syndromes and may be a predictor of death in patients with existing coronary artery disease $[39,40]$. It has been suggested that SICAM-1 is a general marker of proinflammatory status in a healthy population, whereas SVCAM-1 is expressed primarily at an advanced stage of atherosclerosis [40]. After up-regulation of the adhesion molecules in HBMECs and treatment of these cells with palmitic or linoleic acid, we found that palmitic acid significantly increases the level of ICAM-1 and SICAM-1, and sustains the level of VCAM- 1 and SVCAM-1. The results also indicated that linoleic acid maintains the level of ICAM-1 and VCAM-1 in stimulated HBMECS as assessed by ELISA. However, the western blot results indicated a small decrease in the level of VCAM-1. Therefore, it is suggested that palmitic acid could keep the HBMECs at the stimulated phenotype through increased levels of the two forms of ICAM-1 and maintained level of VCAM-1. These findings are consistent with other studies concerning the effect of palmitic acid on up-regulation of adhesion molecules in endothelial cells such as human coronary artery endothelial cells and human umbilical vein endothelial cells (HUVECs) [5, 41, 42]. Our results also indicated that linoleic acid maintains the level of ICAM-1 at an activated level, and could not lower the VCAM-1 significantly in TNF- $\alpha$ or LPSinduced HBMECs. These findings collectively sug- gested that the in vitro atherogenic effect of linoleic acid on HBMECs exceeds its anti-atherogenic effect. Our results are in concordance with several reports about the effect of linoleic acid on up-regulation of adhesion molecules and adhesiveness of endothelial cells [43-46]. Both ICAM-1 and VCAM-1 together mediate adhesion of leukocytes to the activated endothelium and transmigration into the sub-endothelial space [47]. Expression of both VCAM-1 and ICAM-1 is up-regulated in atherosclerotic lesions, although VCAM-1 plays a dominant role in the initiation of atherosclerosis [48]. Since the expression of VCAM-1 occurs only on activated endothelial cells, it may be used as a specific marker of plaque burden or activity. Furthermore, levels of VCAM-1 are prognostically important in acute coronary syndromes [49-51]. Most studies report high plasma concentrations of SVCAM-1 and SICAM1 in coronary artery disease irrespective of stability [52-55].

Collectively, our results indicated that palmitic acid could up-regulate the expression of ICAM-1 and VCAM-1 in HBMECs pretreated with stimulatory agents such as pro-inflammatory cytokines or bacterial LPS. In addition, the results suggested that linoleic acid can sustain up-regulated ICAM-1 and VCAM-1 in activated endothelial cells. Therefore, chronic activation of endothelial cells in the presence of deleterious fatty acids may play a pivotal role in pathogenesis of cardiovascular events. These findings provided further support on the detrimental effects of these fatty acids, specially palmitic acid, in promotion and induction of cardiovascular diseases which are prevalent in the Iranian population. However, more research is needed to characterize the mechanism underlying these effects.

\section{Acknowledgments}

This research was supported by the Medical Biology Research Center (Kermanshah University of Medical Sciences). We would like to thank Dr. Nafiseh Pakravan for editing of the manuscript, and Mr. Shahram Parvaneh and Miss Fariba Ghambari (Medical Biology Research Center, Kermanshah, Iran) for helpful advice on laboratory techniques.

\section{References}

1. Beyk H. Lack of oilseeds production in Iran: Iran imports around one million tons of edible oils. A report from sugar and vegetable oil departments of the Government Trading Corporation of Iran, 2004.

2. Bahrami G, Mirzaeei S. The evaluation of fatty acids profile in available hydrogenation oils and margarines in Iran. Iran Heart J 2003; 4: 59-67.

3. Weisinger HS, Salem NJ, Makino KK, et al. Effect of dietary omega-3 fatty acid deficiency on heart rate variability in hooded rats. Arch Med Sci 2007; 3: 208-14.

4. Tsimikas S, Philis-Tsimikas A, Alexopoulos S, Sigari F, Lee $C$, Reaven PD. LDL isolated from Greek subjects on 
a typical diet or from American subjects on an oleatesupplemented diet induces less monocyte chemotaxis and adhesion when exposed to oxidative stress. Arterioscler Thromb Vasc Biol 1999; 19: 122-30.

5. Thomsen C, Rasmusen O, Lousen T, et al. Differential effects of saturated and monounsaturated fatty acids on postprandial lipemia and incretin responses in healthy subjects. Am J Clin Nutr 1999; 69: 1135-43.

6. Expert Panel on Detection, Evaluation, and Treatment of High Blood Cholesterol in Adults. Executive summary of the third report of the National Cholesterol Education Program (NCEP) expert panel on detection, evaluation, and treatment of high blood cholesterol in adults (Adult Treatment Panel III). JAMA 2001; 285: 2486-97.

7. Institute of Medicine, Food and Nutrition Board. Dietary reference intakes energy, carbohydrate, fiber, fat, fatty acids, cholesterol, protein, and amino acids. Washington: National Academies Press, 2002

8. Mantzioris E, Cleland LG, Gibson RA, Neumann MK, Demasi $M$, James MJ. Biochemical effects of a diet containing foods enriched with n-3 fatty acids. Am J Clin Nutr 2000; 72: 42-8.

9. Penny MK, William SH, Lawrence JA. Fish consumption, fish oil, omega-3 fatty acids, and cardiovascular disease. Circulation 2002; 106: 2747-57.

10. Marc ES. The science behind dietary omega-3 fatty acids. CMAJ 2008; 178: 177-80.

11. Tapiero HG, Nguyen Ba G, Couvreur P, Tew KD. Polyunsaturated fatty acids (PUFA) and eicosanoids in human health and pathologies. Biomed Pharmacother 2002; 56: 215-22.

12. Fiaccavento R, Carotenuto F, Minieri M, et al. Alpha-linolenic acid-enriched diet prevents myocardial damage and expands longevity in cardiomyopathic hamsters. Am J Pathol 2006; 169: 1913-24.

13. Mozaffarian D, Katan MB, Ascherio A, Stampfer MJ, Willett WC. Trans fatty acids and cardiovascular disease. N Engl J Med 2006; 352: 1601-13.

14. Crook MF, Southgate KM, Newby AC. Both ICAM-1- and VCAM-1-integrin interactions are important in mediating monocyte adhesion to human saphenous vein. J Vasc Res 2002; 39: 221-9.

15. Klemke M, Weschenfelder T, Konstandin MH, Samstag Y. High affinity interaction of integrin alpha4betal (VLA-4) and vascular cell adhesion molecule-1 (VCAM-1) enhances migration of human melanoma cells across activated endothelial cell layers. J Cell Physiol 2007; 212: 368-74.

16. Christie MB, Mark LE. Soluble adhesion molecules and the search for biomarkers for atherosclerosis. Circulation 2002; 106: 766-7.

17. Shai I, Pischon T, Hu FB, Ascherio A, Rifai N, Rimm EB. Soluble intercellular adhesion molecules, soluble vascular cell adhesion molecules, and risk of coronary heart disease. Obesity 2006; 14: 2099-106.

18. Rood PM, Calafat J, von dem Borne AE, Gerritsen WR, van der Schoot CE. Immortalization of human bone marrow endothelial cells: characterization of new cell lines. Eur J Clin Invest 2000; 30: 618-29.

19. Arjmandi A, Liu K, Dorovini-Zis K. Dendritic cell adhesion to cerebral endothelium: role of endothelial cell adhesion molecules and their ligands. J Neuropathol Exp Neurol 2009; 68: 300-13.

20. Jacobsen K, Kravitz J, Kincade PW, Osmond DG. Adhesion receptors on bone marrow stromal cells: in vivo expression of vascular cell adhesion molecule-1 by reticular cells and sinusoidal endothelium in normal and gammairradiated mice. Blood 1996; 87: 73-82.
21. Sanadgol N, Mostafaie A, Bahrami G, Mansouri K, Ghanbari F, Bidmeshkipour A. Elaidic acid sustains LPS and TNF-alpha-induced ICAM- 1 and VCAM- 1 expression on human bone marrow endothelial cells (HBMECs). Clin Biochem 2010; 43: 968-72.

22. White DC, Ringelberg DB. Signature lipid biomarker analysis. Techniques in microbial ecology. Oxford University Press, New York 1998; 255-72.

23. Jump DB, Clarke SD, MacDougald O, Thelen A. PUFA inhibit S14 gene transcription in rat liver and cultured hepatocytes. Proc Natl Acad Sci USA 1993; 90: 8454-8.

24. Towbin H, Staehelin T, Gordon J. Electerophoresis transfer of proteins from polyacrylamid gels to nitrocellulose sheet: procedure and some applications. Proc Natl Acad Sci USA 1979; 76: 4350-4.

25. Berenson GS, Srinivasan SR, Bao W, Newman WP, Tracy RE, Wattigney WA. Association between multiple cardiovascular risk factors and atherosclerosis in children and young adults. N Engl J Med 1998; 338: 1650-6.

26. Awtry EH, Loscalzo J. Coronary heart disease. Cecil essentials of medicine. 6th ed. W.B. Saunders, Philadelphia 2000.

27. Denke MA. Dietary fats, fatty acids, and their effects on lipoproteins. Curr Atheroscler Rep 2006; 8: 466-71.

28. Jakobsen MU, O'Reilly EJ, Heitmann BL, et al. Major types of dietary fat and risk of coronary heart disease: a pooled analysis of 11 cohort studies. Am J Clin Nutr May 2009; 89: $1425-32$.

29. Eckel RH, Barouch WW, Ershow AG. Report of the national heart, lung, and blood institute-national institute of diabetes and digestive and kidney diseases working group on the pathophysiology of obesity-associated cardiovascular disease. Circulation 2002; 105: 2923-8.

30. Schaffer JE. Lipotoxicity: when tissues overeat. Curr Opin Lipidol 2003; 14: 281-7.

31. Hansson GK. Inflammation, atherosclerosis, and coronary artery disease. N Engl J Med 2005; 352: 1685-95.

32. Davignon J, Ganz P. Role of endothelial dysfunction in atherosclerosis. Circulation 2004; 109 (23 Suppl. 1): 27-32.

33. Candal FJ, Rafii S, Parker JT, et al. BMEC-1: a human bone marrow microvascular endothelial cell line with primary cell characteristics. Microvasc Res 1996; 52: 221-34.

34. Ridker PM, Hennekens CH, Buring JE, Rifai N. C-reactive protein and other markers of inflammation in the prediction of cardiovascular disease in women. N Engl J Med 2000; 342: 836-43.

35. Malik I, Danesh J, Whincup P, Bhatia V, Papacosta O, Walker M. Soluble adhesion molecules and prediction of coronary heart disease: a prospective study and metaanalysis. Lancet 2001; 358: 971-6.

36. Luc G, Arveiler D, Evans A, et al. Prime study group: circulating soluble adhesion molecules ICAM-1 and VCAM- 1 and incident coronary heart disease: the PRIME Study. Atherosclerosis 2003; 170: 169-76.

37. de Lemos JA, Hennekens CH, Ridker PM. Plasma concentration of soluble vascular cell adhesion molecule1 and subsequent cardiovascular risk. J Am Coll Cardiol 2000; 36: 423-6.

38. Mulvihill NT, Foley JB, Murphy RT, Curtin R, Crean PA, Walsh M. Risk stratification in unstable angina and nonQ wave myocardial infarction using soluble cell adhesion molecules. Heart 2001; 85: 623-7.

39. Blankenberg S, Rupprecht HJ, Bickel C, et al. Circulating cell adhesion molecules and death in patients with coronary artery disease. Circulation 2001; 104: 1336-42.

40. Mulvihill N, Foley B, Crean P, Walsh M. Prediction of cardiovascular risk using soluble cell adhesion molecules. Eur Heart J 2002; 23: 1569-74. 
41. Jiang $\mathrm{H}$, Liang $\mathrm{C}$, Liu $\mathrm{X}$, et al. Palmitic acid promotes endothelial progenitor cells apoptosis via p38 and JNK mitogen-activated protein kinase pathways. Atherosclerosis 2010; 210: 71-7.

42. Reissig D, Rassoul F, Salvetter J, Wagner O, Richter V. Effect of fatty acids on expression of endothelial leukocyte adhesion molecules. Eur J Nutr 2003; 42: 224-7.

43. Park HJ, Lee YW, Hennig B, Toborek M. Linoleic acidinduced VCAM-1 expression in human microvascular endothelial cells is mediated by the NF-kappa B-dependent pathway. Nutr Cancer 2001; 41: 126-34.

44. Hennig B, Meerarani P, Ramadass P, Watkins BA, Toborek M. Fatty acid-mediated activation of vascular endothelial cells. Metabolism 2000; 49: 1006-13.

45. Hennig B, Lei W, Arzuaga X, Ghosh DD, Saraswathi V, Toborek M. Linoleic acid induces proinflammatory events in vascular endothelial cells via activation of PI3K/Akt and ERK1/2 signaling. J Nutr Biochem 2006; 17: 766-72.

46. Young VM, Toborek M, Yang F, et al. Effect of linoleic acid on endothelial cell inflammatory mediators. Metabolism 1998; 47: 566-72.

47. van Buul JD, van Rijssel J, van Alphen FP, van Stalborch AM, Mul EP, Hordijk PL. ICAM-1 clustering on endothelial cells recruits VCAM-1. J Biomed Biotechnol 2010; 2010: 120328.

48. Cybulsky MI, liyama K, Li H, et al. A major role for VCAM-1, but not ICAM-1, in early atherosclerosis. J Clin Invest 2001; 107: $1255-62$

49. Jager A, van Hinsbergh VW, Kostense PJ. Increased levels of sVCAM-1 are associated with risk of cardiovascular mortality in type 2 diabetes. Diabetes 2000; 49: 485-91.

50. Blankenberg S, Rupprecth HJ, Bickel C. Circulating cell adhesion molecules and death in patients with coronary artery disease. Circulation 2001; 104: 1336-42.

51. Mulvihill NT, Foley JB, Murphy RT. Inflammatory markers predicting outcome in unstable angina and non Q-wave myocardial infarction. Heart 2001; 85: 623-7.

52. Ronette R, Briefel Clifford L Secular trends in dietary intake in the United States. Annu Rev Nutr 2004; 24: 401-31.

53. Guray U, Erbay AR, Guray Y. Levels of soluble adhesion molecules in various clinical presentations of coronary atherosclerosis. Int J Cardiol 2004; 96: 235-40.

54. Vasa M, Fichtlscherer S, Aicher A. Number and migratory activity of circulating endothelial progenitor cells inversely correlate with risk factors for coronary artery disease. Circ Res 2001; 89: E1-7.

55. Hill JM, Zalos G, Halcox JP. Circulating endothelial progenitor cells, vascular function, and cardiovascular risk. N Engl J Med 2003; 348: 593-600. 